\title{
One Story, Too Much Sorrow
}

Juan Piazze $^{1 *}$, Assunta Lombardi ${ }^{2}$, Arianna Amata $^{3}$, Anna Maria Petitti ${ }^{4}$

${ }^{1}$ ASL Frosinone (Consultorio Familiare di Frosinone, Casa della Salute di Ceprano, Ospedale SS Trinità di Sora) Frosinone, Lazio.

${ }^{2}$ Social Assistance Albo B, Frosinone, Lazio.

${ }^{3}$ Centro AEMME. Anagni, Frosinone.

${ }^{4}$ ASL Frosinone (Chief physician of UOSD, Consultorio e percorso nascita) Frosinone, Lazio.

*Corresponding Author: Juan Piazze, Juan Piazze, ASL Frosinone (Consultorio Familiare di Frosinone, Casa della Salute di Ceprano, Ospedale SS Trinità di Sora) Frosinone, Lazio.

Received Date: March 11, 2021; Accepted Date: March 18, 2021; Published Date: March 22, 2021

Citation: Juan Piazze, Assunta Lombardi, Arianna Amata, Anna Maria Petitti (2021) One Story, Too Much Sorrow. J Women Health Care Issues, 4(2); Doi:10.31579/2642-9756/044

Copyright: (C) 2021 Juan Piazze, This is an open-access article distributed under the terms of the Creative Commons Attribution License, which permits unrestricted use, distribution, and reproduction in any medium, provided the original author and source are credited.

\section{Abstract}

More than "usual" pregnancies adequately followed up and with precise scheduled timing, other pregnant women reach our outpatient services.

Key words: complicated pregnancy; public health service; charity programs

\section{Introduction}

More than "usual" pregnancies adequately followed up and with precise scheduled timing, other pregnant women reach our outpatient services. And many times they are desperate cases, not only hard to manage but to make them deliver uneventfully. The follow up of these complicated pregnancies could not be possible, if charity programs and other similar institutions would not cooperate firmly with the public health institutions [1].

These different social organizations work together with regional prefectures, and act as a link between these women and the public health system.

This manuscript regards a sad story that may represent those thousands of pregnancies that the above mentioned charity organizations help to support until birth and many times afterwards.

\section{Case Presentation}

Pretious was born in Okwu Orodo, a poor village situated at the Imo state. Her family was particularly poor, and even frequenting school was impossible for her. In fact, they sent her to school for only four years, and then no more. She had other five brothers and sisters.

One of her brothers suffered an illness (not well specified), and almost all the family's economical resources ended in the hands of shamans or medicine men that introduced healing lotions or other potions directly through the skin near the cheeks and the superior abdominal wall. Due to all this miserable situation, and at the age of fourteen, Pretious decides to move to Benin city in order to learn the hairdresser job. At the Benin city, she finds her life companion.

When she was pregnant of the second child, the mate had an accident and after four days died.

Pretious was christian, and the companion was mushlim. This was the reason why his family takes advantage of this condition in order to evict Pretious and her child from their home, with no money, in an advanced ongoing pregnancy and gulty of professing a different religion. At the beginning, she tried to take refuge at the beauty parlor place where she used to work, but very soon the situation was impossible to sustain. So she asked for help to the local minister who predisposed an appartment for her and her two years old child. After three years of apparent quietness, the place where she worked was worn out by a fire that consumed all the zone. From that moment, she arranged in order to sell water at the market, taking always her two babies with her.

Unexpectedly, one day a man presented and offered her to change her life and talked about a better future for her and her children. Intrigued about the offer of a decent life prospected by this unknown man, she decided to accept the invitation. She would have to leave towards an unknown destination, where they would take her for the first "meeting" and an eventual contract. Due to the the fact that she had no references in town, she would have to entrust her children to the unknown man's mother.

The only things clear were that she would have to pay for this transfer and that she would work as a beauty parlor once reached the unknown destination.

After hours of travel, through places completely new to her, they arrived. She was a part of a couple of women who were accompanied inside a dark room, with no lights but one candle to shine a soft light. Suddenly, the men in this room made her swear that she would have paid for all these "facilities", and to be sure, they cut a lock of hair, some drops of blood sampled from her finger and a piece of nail, in order to confirm the oath.

When they told her that if the payment was not carried out, they would have tortured her children and family until a painful death, she understood her incorrect choice. All those offers of a new future were actually a great lie.

Then she was taken to Niger, then Ghatron and finally in Libia. Then again to Saba and to Tripoli. At Tripoli other six women in her same desperate situation added to the group. And they all were "sold" to a Nigerian lady, Yoruba. Then again they were stolen by another Libian 
group, that took them to an unknown place where they were continuously raped, tortured and bitten. In order to trick herself form all these suffering, she used to sing in Ibo, her mother language. One of her surveillants heard her sing and pray in that language and with no apparent reason, he compromised to take her away to a safe place. Then he took her to a seaside town at Moureen, and in this place, she met again that unknown man that took her initially to Libia.

And he put in contact Pretious with her mother (that had her two babies in custody). That lady was known as a "Madame", who had decided to send Pretious in Europe, to work as a prostitute in the middle of the streets. By that time, Pretious realized to be pregnant again, not knowing the father of the baby in womb, from the men that raped her continuously with absolutely no protection.

After one month, she was the the part of a group of immigrants who were sent to Italy inside a ramshackle dinghy. At the arrival time, she was textually trampled by all the other people; she saved herself making understand she was pregnant and she was inmediatly taken in charge by a charity institution. Finally under protection, she was sent to the emergency room and after stabilizing her pregnancy situation, she became part of the pregnant care program of this human care institution.

Unfortunately, the conditions of the dangerous trip to Italy, the physycal trauma suffered at the arrival and the health status of Pretious, lead to a preterm delivery at 26 wks' gestation (as calculated by ultrasound biometry performed in our outpatient Division).

A spontaneous delivery of a 500 gr male newborn, affected by severe respiratory failure and other severe complications verified.
Now after three years, the baby presents a severe cognitive delay an has an oxygen cylinder as his more trustly friend. With Pretious taking accurate care of him, for the rest of their lives.

\section{Final Comment}

Critical situations involve several countries and these homeless pregnant patients are a vulnerable population, that without the charity institutions, would be left to different risky situations $(2,3)$.

Violence, infibulation, injustice, racism, exploitation.

The clinical operators of the public health service, should thank those silent workers from all charity programs and institutions, that give an important hand with their sacrifice and with their, many times, not understood mission.

All names involved are fictitious in order to respect the individual privacy.

\section{Declaration of conflicting interests:}

The author(s) declared no potential conflicts of interest with respect to the research, authorship, and/or publication of this article.

\section{References}

1. Valuing charity. Kronick R. J Health Polit Policy Law 2001;26:993-1001.

2. Health service access and utilization among Syrian refugees in Jordan.Doocy S, Lyles E, Akhu- Zaheya L, Burton A, Burnham G. Int J Equity Health 2016;4;108.

3. Public vs. private provision of charity care? Evidence from the expiration of Hill-Burton requirements in Florida. Almond D, Currie J, Simeonova E.J. Health Econ 2011;30:189-199.

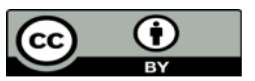

This work is licensed under Creative Commons Attribution 4.0 License

To Submit Your Article Click Here: Submit Manuscript

DOI:10.31579/2642-9756/044
Ready to submit your research? Choose Auctores and benefit from:

* fast, convenient online submission

* rigorous peer review by experienced research in your field

* rapid publication on acceptance

* authors retain copyrights

* unique DOI for all articles

* immediate, unrestricted online access

At Auctores, research is always in progress.

Learn more www.auctoresonline.org/journals/women-health-care-andissues 